\title{
Influence of Duroc breed inclusion into Polish Landrace maternal line on pork meat quality traits
}

\author{
DOMINIKA GUZEK ${ }^{1}$, DOMINIKA GŁĄBSKA ${ }^{2}$, KRZYSZTOF GŁĄBSKI $^{3}$ and AGNIESZKA WIERZBICKA ${ }^{4}$ \\ ${ }^{1}$ Laboratory of Food Chemistry, Faculty of Human Nutrition and Consumer Sciences, Warsaw University \\ of Life Sciences (WULS-SGGW), 159c Nowoursynowska str., 02-776 Warsaw, Poland \\ ${ }^{2}$ Department of Dietetics, Faculty of Human Nutrition and Consumer Sciences, Warsaw University \\ of Life Sciences (WULS-SGGW), 159c Nowoursynowska str., 02-776 Warsaw, Poland \\ ${ }^{3}$ Department of Microbial Biochemistry, Institute of Biochemistry and Biophysics, Polish \\ Academy of Sciences (PAS-PAN), 5a Pawinskiego str., 02-106 Warsaw, Poland \\ ${ }^{4}$ Department of Technique and Food Development, Faculty of Human Nutrition and Consumer Sciences, Warsaw \\ University of Life Sciences (WULS- SGGW), 159c Nowoursynowska str., 02-776 Warsaw, Poland
}

Manuscript received on December 15, 2014; accepted for publication on August 10, 2015

\begin{abstract}
Crossbreeding with Duroc breed allows to improve meat quality, but no data is available regarding specific influence of Duroc breed on characteristics of meat in the case of crossbreeding with various breeds. The aim of the present research was to evaluate the effect of crossbreeding Polish Landrace dames with Duroc sires on quality features of meat in reference to Polish Landrace breed. The objects of the study were Longissimus dorsi lumborum pork muscles obtained from Polish Landrace breed and Polish Landrace $\mathrm{x}$ Duroc crossbreed animals. Sarcomere length measurements were conducted using microscopic method and basic chemical composition measurement was analyzed using spectrophotometric scanning. Texture analysis of meat samples, performed after thermal treatment was expressed by Warner-Bratzler shear force and color analysis was obtained using CIE L*a*b* color system. No differences in sarcomere length, shear force as well as components of color values between pork meat originated from Polish Landrace breed and Polish Landrace x Duroc crossbreed were observed. Analysis of basic chemical composition revealed higher fat and lower ash contents in the case of meat of Polish Landrace breed animals. It was concluded that the actual impact of breed on meat characteristics is possibly altered by other factors. It may be suggested that influence of basic chemical composition on color of meat is breed-related.
\end{abstract}

Key words: pork, sarcomere length, protein and fat content, shear force, color.

\section{INTRODUCTION}

In the past, crossbreeding was primarily used mainly to increase total efficiency of pork production, however, such procedures could be associated with negative impact on meat palatability, particularly tenderness (Lonergan et al. 2001). Nowadays, pork

Correspondence to: Dominika Guzek

E-mail: dominika_guzek@sggw.pl crossbreeding is perceived as method helping to improve meat quality (Jiang et al. 2012). In Poland, production of pork crossbreed was based on crossing Polish Large White or Polish Landrace dams with Pietrain, Duroc or Hampshire sires (Blicharski and Hammermeister 2013). It was observed that the most significant improvement of meat quality was associated with crossbreeding with Duroc breed (Ramírez and Cava 2007). 
On the basis of various researches it was concluded that, among all meat quality traits, tenderness (Dilger et al. 2010) and color (Lindahl et al. 2006) are the most important sensory attributes of pork meat. Factors involved in determination of such sensory features may vary, but researches focused on analysis of tenderness variation in the case of major pork muscles and indicated the distinctive role of sarcomere length in creating texture of unaged pork muscles (Wheeler et al. 2000). Simultaneously, it was suggested that meat color may be influenced by the deposition of dietary components in the muscles and fat tissue, being mainly an effect of specified feeding regime (Tikk 2007).

There is no data regarding specific influence of the Duroc breed on meat characteristics (especially on the most important features, such as texture and color) in the case of crossbreeding with various breeds. The aim of the present research was to evaluate the effect of crossbreeding Polish Landrace dames with Duroc sires on the quality features of meat (including sarcomere length, shear force, basic composition and color) in reference to Polish Landrace breed.

\section{MATERIALS AND METHODS}

\section{EXPERIMENT}

The present experiment was carried out in the laboratory of Warsaw University of Life Sciences, Warsaw, Poland. The objects of the study were pork loins (Longissimus dorsi lumborum muscle) obtained from 6 animals of Polish Landrace breed and from 5 animals of Polish Landrace x Duroc crossbreed, derived from task 3 of the project "Biofood - innovative, functional products of animal origin" co-financed by the European Union from the European Regional Development Fund within the Innovative Economy Operational Programme 2007-2013. The selected animals were characterized by the similar mass $(100 \pm$ $15 \mathrm{~kg}$ ), same age (5-6 months, according to the
Pork Quality System) and were raised together with an experimental farm. In the case of each animal standard animal management (animals under veterinary care, management typical for animal husbandry in food production according to Polish law regulation) and slaughter procedure (commercial facility) was applied. Obtained meat was characterized by the appropriate $\mathrm{pH}$ value.

The analyzed animals were fed fodder containing $2 \%$ of canola oil. Basic fodder contained barley grits $(360 \mathrm{~g} / \mathrm{kg}$ of the fodder), wheat middlings $(360 \mathrm{~g} / \mathrm{kg}$ of the fodder), corn grits $(100 \mathrm{~g} / \mathrm{kg}$ of the fodder), extracted soybean meal $(80 \mathrm{~g} / \mathrm{kg}$ of the fodder), extracted rapeseed meal (40 g/ $\mathrm{kg}$ of the fodder) and vitamin-mineral premix $(25 \mathrm{~g} / \mathrm{kg}$ of the fodder). The dry matter for applied diet was 903 $\mathrm{g} / \mathrm{kg}$, while metabolizable energy was $13,5 \mathrm{MJ} / \mathrm{kg}$ of dry matter. The detailed chemical composition of the applied control diet was described in the previous paper (Guzek et al. 2012b).

The tested samples were routinely obtained from federally inspected slaughter facilities and special approval from Animal Care and Use Committee is not required.

SARCOMERE LENGTH MEASUREMENT

Sarcomere length was measured according to the method of Cross et al. (1981) with minor modifications (Guzek et al. 2012a, 2015). In the case of each cut, representative $5 \mathrm{~g}$ meat samples were collected and homogenized in $30 \mathrm{ml}$ of cold $0.25 \mathrm{M}$ sucrose solution at low speed (mechanical homogenizer PRO 200, PRO Scientific Inc., Connecticut, USA - $5000 \mathrm{rpm}, 60$ seconds). The appropriate volume of the homogenized sample (5$10 \mu 1)$ was placed on the microscopic slide, covered with the cover slip and subjected to microscopic observations. The evaluation of the sarcomere length was conducted using Carl Zeiss Axio Imager.M2 microscope (Carl Zeiss, Oberkochen, Germany) with EC Plan-Neofluar 100x/1.30 Oil $\mathrm{Ph} 3 \mathrm{M} 27$ objective and AxioCamMR5 camera. 
Microscopic preparations were observed in the differential interference contrast (DIC). Sarcomere length values were measured using AxioVision Rel.4.8.2 software (Carl Zeiss, Oberkochen, Germany). The 3 myofibrils were selected for each sample and lengths of 10 sarcomeres for each myofibril were measured.

\section{BASIC CHEMICAL COMPOSITION MEASUREMENT}

In the case of each cut, representative $150 \mathrm{~g}$ meat samples were collected and homogenized with a blender for $30-60$ s to obtain a homogeneous mixture. Samples were placed on a Petri dish (diameter - $90 \mathrm{~mm}$ ) in NIR device (NIR Flex Solids N-500, Büchi, Flawil, Switzerland - spectral range 800 to $2,500 \mathrm{~nm}$ ). Spectrophotometer scanning was performed three times for each sample, according to the widely applied methodology (Prevolnik et al. 2004). Spectral analysis software NIR Ware 1.1 and NIR Cal 5.1 (Büchi, Flawil, Switzerland) was used to collect and calculate results. Water, protein, fat, ash and collagen contents (\%) were measured for each sample.

\section{TEXTURE ANALYSIS}

In order to carry out texture analysis, meat samples were studied according to the widely applied methodology (AMSA 1995). Pork cuts were subjected to thermal treatment with a steam-convection oven (Küppersbusch CPE 110, Küppersbusch Grobküchentechnik $\mathrm{GmbH}$, Gelsenkirchen, Germany) until an internal temperature of $71^{\circ} \mathrm{C}$ was reached. After thermal treatment each cut was divided into steaks and samples were chilled at $2 \pm 1^{\circ} \mathrm{C}$. Subsequently, coring procedure aimed at obtaining cores with uniform diameter was conducted. Six cores of 1.27 $\mathrm{cm}$ diameter were sheared perpendicular to the longitudinal orientation of the muscle fibers with Instron 5965 Universal Testing Machine (Instron, Canton, Massachusetts, USA) equipped with 500
$\mathrm{N}$ load cell. The Warner-Bratzler shear force [N] was recorded as the first highest peak on the forcedeformation curve for samples.

COMPONENTS OF COLOR ANALYSIS

Meat samples were subjected to color components analysis. For each sample $8 \mathrm{~mm}$ diameter measurement area was applied. Color components were measured using Hunter Lab chromometer Minolta CR-400 (Minolta Camera Co., Osaka, Japan) with D65 standard illuminant. The chromometer was previously calibrated against standard white reference tile (CR-A43). Ten measurements for each sample from various steak locations excluding marbling areas were conducted, according to the recommended methodology (Hunt et al. 1991). The L* (lightness), a* (bluish-green/ red-purple hue component), $b^{*}$ (yellow/ blue hue component) and hue angle values were collected for all the samples. Hue angle values were calculated, as [arctangent $\left(b^{*} / a^{*}\right)^{*} 180 / 3.142$ ], expressed in degrees (King et al. 2011).

\section{STATISTICAL ANALYSIS}

W Shapiro-Wilk test was used to verify the normality of distribution. T-Student and U-Mann-Whitney tests were used to compare resultant values between breeds. To define the significance, the level $\alpha=0.05$ was accepted. Statistic analysis was conducted using the Statistica software version 8.0 by StatSoft (Tulsa, Oklahoma, USA).

\section{RESULTS}

Sarcomere length values, measured for meat samples representative for Polish Landrace breed and Polish Landrace x Duroc crossbreed animals, are presented in Figure 1 (a) and Figure 1 (b), respectively. It was concluded that no statistically significant differences were observed between sarcomere length values for pork meat samples originated from both groups ( $\mathrm{p}>0.05)$. 


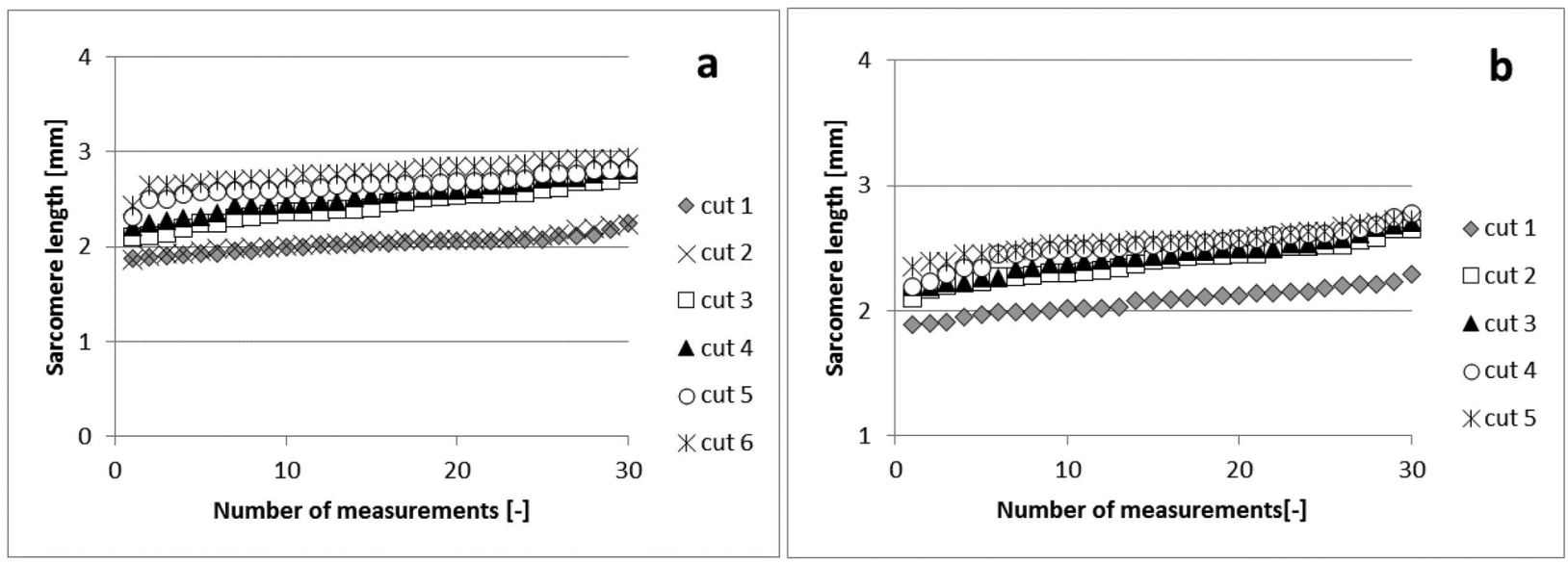

Figure 1 - (a). Sarcomere length values $[\mu \mathrm{m}]$ for the analyzed 6 cuts of Polish Landrace breed animals, (b). Sarcomere length values $[\mu \mathrm{m}]$ for the analyzed 5 cuts of Polish Landrace $\mathrm{x}$ Duroc crossbreed animals.

Water contents, measured for meat samples derived from Polish Landrace breed and Polish Landrace $x$ Duroc crossbreed animals, are presented in Figure 2 (a). Lack of statistically significant differences between both breeds was observed, however, it may be indicated that identified differences were close to significance $(\mathrm{p}<0.1)$.

Protein contents, measured for meat samples from animals representing Polish Landrace breed and Polish Landrace x Duroc crossbreed, are presented in Figure 2 (b). Lack of statistically significant differences between animals from both groups was observed ( $\mathrm{p}>0.05)$.

Fat contents, measured for meat samples derived from Polish Landrace breed and Polish Landrace $x$ Duroc crossbreed animals, are presented in Figure 2 (c). Statistically significant differences between meat samples from breed and crossbreed animals were observed $(p<0.01)$. Meat obtained from Polish Landrace breed animals was characterized by higher fat content than in the case of Polish Landrace x Duroc crossbreed samples.

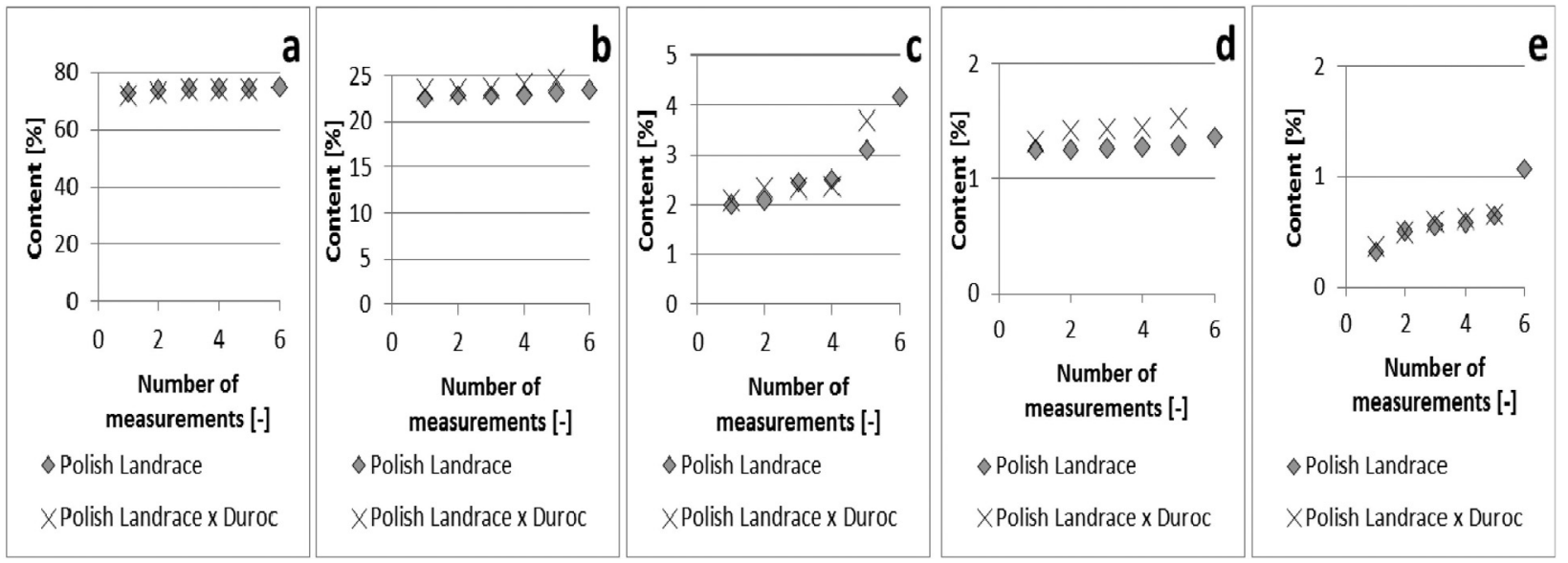

Figure 2 - (a). Water content values [\%] for the analyzed 6 cuts of Polish Landrace breed and 5 cuts of Polish Landrace x Duroc crossbreed animals $(\mathrm{p}<0.1)$; (b). Protein content values [\%] for the analyzed 6 cuts of Polish Landrace breed and 5 cuts of Polish Landrace $x$ Duroc crossbreed animals $(\mathrm{p}>0.1)$; (c). Fat content values [\%] for the analyzed 6 cuts of Polish Landrace breed and 5 cuts of Polish Landrace $x$ Duroc crossbreed animals $(p<0.01)$; (d). Ash content values [\%] for the analyzed 6 cuts of Polish Landrace breed and 5 cuts of Polish Landrace $x$ Duroc crossbreed animals $(p<0.05)$; (e). Collagen content values [\%] for the analyzed 6 cuts of Polish Landrace breed and 5 cuts of Polish Landrace $x$ Duroc crossbreed animals ( $>0.05)$. 
Ash contents, measured for meat samples from Polish Landrace breed and Polish Landrace x Duroc crossbreed animals, are presented in Figure 2 (d). Statistically significant differences between meat samples representing both groups were observed $(p<0.005)$. Meat samples obtained from Polish Landrace $\mathrm{x}$ Duroc crossbreed animals were characterized by higher ash content than those measured in the case of Polish Landrace breed animals.

Collagen contents, measured for samples originated from Polish Landrace breed and Polish
Landrace x Duroc crossbreed animals, are indicated in Figure 2 (e). Lack of statistically significant differences between breed and crossbreed animals was observed $(p>0.05)$.

Shear force values, measured for meat samples derived from Polish Landrace breed and Polish Landrace $x$ Duroc crossbreed animals, are presented in Figure 3 (a) and Figure 3 (b), respectively. No statistically significant differences between values obtained from both breeds animals were observed $(\mathrm{p}>0.05)$.
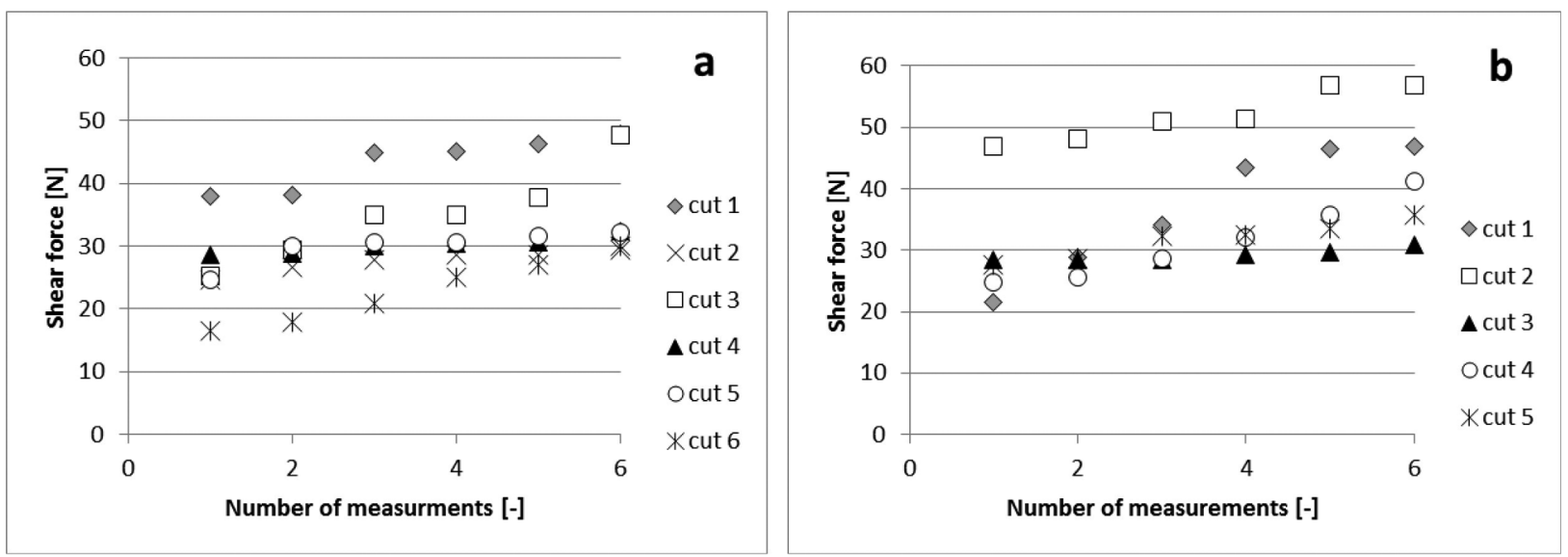

Figure 3 - (a). Shear force values [N] for the analyzed 6 cuts of Polish Landrace breed animals; (b). Shear force values [N] for the analyzed 5 cuts of Polish Landrace x Duroc crossbreed animals

Values of $\mathrm{L}^{*}, \mathrm{a}^{*}$ and $\mathrm{b}^{*}$ components of color, as well as hue angle, measured for meat obtained from Polish Landrace breed and Polish Landrace $\mathrm{x}$ Duroc crossbreed animals, are presented in Table I. No statistically significant differences were observed between components of color for meat originated from both breeds $(p>0.05)$, while for hue angle significant differences were observed $(p=0.0000)$.

\section{DISCUSSION}

Sarcomere length values may be partly determined by genetic factors including breed. On a level of cytoskeleton and contractile fiber structure, genetically determined interactions between actin filaments promote elongation of thin filaments, possibly contributing to higher sarcomere length (Tsukada et al. 2010). Simultaneously, sarcomere length values observed for meat samples may result to some extent from post-slaughter handling, including electrical stimulation and hanging. In addition, it was previously described that sarcomere length values are used to determine incidence of the cold-shortening in beef meat (Muchenje et al. 2009) as one of the factors related to general meat quality.

Sarcomere length is generally positively correlated with meat tenderness (Smulders et al. 1990). In the case of detailed comparison between pork meat samples it was observed that Semitendinosus and Triceps branchii muscles, characterized by the highest sarcomere lengths, are simultaneously 
TABLE I

The median (min - max) values of meat color of Polish Landrace breed animals and Polish Landrace $x$ Duroc crossbreed animals.

\begin{tabular}{|c|c|c|c|c|c|}
\hline & & $\mathrm{L} *(\mathrm{D} 65)$ & $\mathrm{a}$ *(D65) & $b^{*}(\mathrm{D} 65)$ & $\mathrm{H}^{*}$ \\
\hline \multirow{6}{*}{$\begin{array}{l}\text { Polish Landrace } \\
\text { breed animals }\end{array}$} & Cut 1 & $55.9(53.7-58.5)$ & $6.8(4.9-7.8)$ & $3.9(2.6-5.4)$ & $30.3(26.1-35.4)$ \\
\hline & Cut 2 & $55.3(52.9-59.2)$ & $7.4(5.9-8.9)$ & $4.4(2.9-6.1)$ & $30.1(26.1-35.4)$ \\
\hline & Cut 3 & $50.2(45.8-55.2)$ & $7.6(6.8-10.5)$ & $3.2(1.0-5.7)$ & $23.2(8.4-28.7)$ \\
\hline & Cut 4 & $52.9(48.3-55.3)$ & $6.1(5.5-7.1)$ & $3.0(1.2-4.5)$ & $26.1(12.9-32.5)$ \\
\hline & Cut 5 & $56.9(51.4-58.5)$ & $6.9(5.7-8.0)$ & $3.9(2.5-5.1)$ & $30.2(23.8-33.8)$ \\
\hline & Cut 6 & $53.3(49.9-57.0)$ & $9.0(7.5-10.7)$ & $5.0(3.2-7.0)$ & $29.6(21.9-34.7)$ \\
\hline \multirow{5}{*}{$\begin{array}{l}\text { Polish Landrace } \mathrm{x} \\
\text { Duroc crossbreed } \\
\text { animals }\end{array}$} & Cut 1 & $55.13(53.6-58.2)$ & $8.3(6.8-10.2)$ & $5.1(4.1-8.8)$ & $32.9(30.6-40.7)$ \\
\hline & Cut 2 & $58.1(56.2-62.7)$ & $5.9(5.2-7.2)$ & $5.1(4.2-6.6)$ & $41.1(38.8-42.4)$ \\
\hline & Cut 3 & $54.1(51.7-57.8)$ & $6.0(4.7-7.1)$ & $3.1(1.6-5.5)$ & $29.0(18.9-38.3)$ \\
\hline & Cut 4 & $61.1(59.0-62.5)$ & $8.0(5.5-9.9)$ & $8.4(5.1-9.4)$ & $44.3(38.3-47.8)$ \\
\hline & Cut 5 & $60.3(59.3-63.2)$ & $5.5(4.0-6.7)$ & $6.0(3.6-7.8)$ & $47.4(41.9-52.1)$ \\
\hline p-Value ${ }^{1}$ & & $\mathrm{p}>0.05$ & $\mathrm{p}>0.05$ & $\mathrm{p}>0.05$ & $\mathrm{p}=0.000$ \\
\hline
\end{tabular}

${ }^{1}$ for nonparametric distribution U Mann-Whitney test was conducted.

described by the highest tenderness (higher rating in sensory evaluation and lower values of WarnerBratzler shear force) (Wheeler et al. 2000).

In the present research, similarly to other studies, lack of significant differences in sarcomere length as well as shear force values between Polish Landrace breed and Polish Landrace $\mathrm{x}$ Duroc crossbreed animals was observed. Wood et al. (1996) identified no significant differences in meat tenderness between Duroc and Large White breed animals. On the other hand, previous studies indicated significant influence of breed on tenderness. In the research of Jeleníková et al. (2008), significant differences in tenderness between Large White, Czech Landrace and Duroc breeds were obtained, namely the highest tenderness was observed in the case of cooked Duroc breed meat simultaneously higher rated in sensory analysis and lower rated in instrumental measurements (indicating more tenderness). Simultaneously, in the research of Thornton et al. (1968), Longissimus dorsi muscle derived from meat form Duroc breed was characterized by the higher tenderness than meat from Yorkshire breed animals. In the research of Crawford et al. (2010), measured values of Warner-Bratzler shear force were significantly higher for Landrace breed than for Berkshire breed meat.

The differences between results obtained in different groups may be associated with the different sets of breeds analyzed in the case of each of the mentioned researches. However, it was described in the research of Josell (2002) that genotype (presence of $\mathrm{RN}$ allele) may potentially play more important role than breed. In the mentioned study it was revealed that the Warner-Bratzler shear force values were found to be lower for Longissimus dorsi muscle from RN allele-positive animals (being more tender), while the same samples sensory panel evaluation indicated higher values (also meaning more tender meat) for the same muscle from RN allele-negative animals, regardless of breed (Josell 2002). Indeed, it might be concluded that not only breed, but also other genetic factors may influence pork meat tenderness and as a result modify the identified influence of breed. On the other hand, in the present research, in contrast to the studies of Jeleníková et al. (2008) and Thornton et al. (1968), the highest tenderness values in the case of Duroc breed meat were not confirmed. 
Simultaneously, there are several studies but not for pork, trying to evaluate influence of breed on sarcomere length. In the work of Lewis et al. (1977), analyses carried out for an uncooked or cooked Longissimus dorsi beef muscle revealed no influence of dam breed (Angus or Hereford breeds) on sarcomere length, as well as no change in sarcomere length due to cooking process. On the other hand, in this research, analysis for Longissimus dorsi muscle revealed also influence of sire breed (Angus, Hereford, Santa Gertrudis or Charolais breeds) on change in sarcomere length resulting from cooking and sarcomere length after cooking (Lewis et al. 1977).

However, similarly as in the case of tenderness, breed influence on sarcomere length might be modulated by genotype. In the research of Monin et al. (1999), analyses of the influence of three HAL genotypes (NN, Nn, and nn alleles) on sarcomeres in meat samples obtained from Pietrain x Large White crossbreed animals, revealed that sarcomere length in the case of nn allele was higher than for $\mathrm{NN}$ and Nn alleles.

It should be noted that the mentioned research did not include analyses for Duroc breed and crossbreeds, so it seemed hard to determine if the obtained results are typical. However, taking into account the identified correlation between sarcomere length and pork tenderness (Wheeler et al. 2000), it was highly expected to obtain no differences between Polish Landrace breed and Polish Landrace x Duroc crossbreed animals, both in the case of sarcomere length and shear force values.

Basic chemical composition of meat may be influenced by a wide range of factors, among them genetics (including breed and gender), feeding regime including supplementation, slaughter age and season. Chemical composition of meat, especially proportion of lean meat to fat, is a basic quality feature and one of the elements creating meat quality according to the definition of Food and Agriculture Organization of the United Nations (FAO 1990).

Data regarding meat composition might be obtained by the spectrophotometric method, especially during quick, on-line analyses. Spectrophotometric method allows to predict only limited number of factors, but is perceived as a faithful method giving an opportunity to specify the differences between meat samples, particularly to categorize meat into quality classes or to discriminate between production factors (Prevolnik et al. 2004).

Chemical composition of meat may affect to some extent oxidation processes. As a consequence, both fat (Ismail et al. 2009) and protein oxidation processes (Rowe et al. 2004) might contribute to resultant color of meat.

In the present research, Duroc breed inclusion into Polish Landrace maternal line influenced distinct elements of basic chemical composition, especially fat and ash contents. Similar observations were made by Wood et al. (2004), who identified in the case of Duroc and Berkshire breeds higher total fatty acids content than for Large White and Tamworth breeds, with simultaneous differences in proportions of fatty acids. In the case of other breeds influence of breed on basic chemical composition was also generally observed.

In the research of Teixeira and Rodrigues (2013), in the case of comparison between Preto Alentejano (Portuguese black pork) breed and Large White $\mathrm{x}$ Landrace crossbreed, influence of breed on protein, total fat, pigments and dry matter contents but not ash content was observed. In the mentioned study, Preto Alentejano breed was characterized by especially high fat content (Teixeira and Rodrigues 2013). In the study conducted by Kim et al. (2008), differences in water, crude protein and total amino acid contents were observed; water content was the highest for Kagoshima Berkshire breed, crude protein content for $<$ Yorkshire $\times$ Berkshire $>\times$ Berkshire crossbreed and Kagoshima Berkshire 
breed, whereas total amino acid content for $<$ Landrace $\times$ Yorkshire $>\times$ Duroc crossbreed and British Berkshire breed. In the results presented by Florowski et al. (2006a), breed-related differences in basic chemical composition of pork meat, but not in ash content, were also observed. In the discussed work, it was concluded that water content in the case of Polish Landrace breed was higher than for Zlotnicka Spotted and Pulawska breeds. Simultaneously, protein content was the lowest for Polish Landrace breed as well as fat content was the highest in the case of Zlotnicka Spotted breed, and the lowest in the case of Polish Landrace breed (Florowski et al. 2006a). Generally, it might be concluded that changes in fat content are often associated with breed but ash content seems to be resistant to breed alterations. However, it should be noted that in the present research such influence of Duroc breed inclusion into Polish Landrace maternal line was observed.

In the case of color analysis, differences between breeds were observed in several studies, e.g. in the research of Gjerlaug-Enger et al. (2010) presenting comparison of $\mathrm{L}^{*}, \mathrm{a}^{*}$ and $\mathrm{b}^{*}$ components of color between Duroc and Landrace breeds. On the other hand, in previously mentioned Polish research of Florowski et al. (2006a), in the case of comparison between Polish Landrace, Zlotnicka Spotted and Pulawska breeds, no differences in $\mathrm{L}^{*}$ component of color were observed, despite significant differences in basic chemical composition. Similarly, in other research of the same team (Florowski et al. 2006b), although Pietrain breed was characterized by significantly the highest components of color, no differences in $\mathrm{L}^{*}, \mathrm{a}^{*}$ and $\mathrm{b}^{*}$ components were identified between Duroc, Polish Landrace, Polish White and Line 990 breeds. Moreover, in the mentioned research of Florowski et al. (2006b), comparison of water and fat contents revealed similar difference as in another article (Florowski et al. 2006a). On the basis of present study, when Polish Landrace $x$
Duroc crossbreed animals were compared with Polish Landrace breed animals, it may be suggested that the observation regarding lack of influence of lower fat and higher ash contents, on color of meat is typical. It is probably the consequence of the predominant influence of other factors on color of meat, among them muscle, diet and aging (Tikk 2007). The significant differences of hue angle are difficult to discuss, as in none of the mentioned research studies it was assessed. Simultaneously, as Pietrain breed was characterized by the different basic chemical composition and color of meat than other breeds (Florowski et al. 2006b), it may be concluded that chemical composition affects color of pork meat in a breed-related manner.

On the basis of the conducted research it may be concluded that Duroc breed inclusion into Polish Landrace maternal line contributes to changes in basic chemical composition of obtained meat, although it alters change neither in sarcomere length nor the quality features recognized by consumers (texture, color).

\section{CONCLUSIONS}

1. Duroc breed inclusion into Polish Landrace maternal line does not contribute to differences in sarcomere length and shear force values in comparison with Polish Landrace breed; 2. Duroc breed inclusion into Polish Landrace maternal line contributes to differences in basic chemical composition, however, no differences in color were observed in comparison with Polish Landrace breed; 3. Influence of basic chemical composition on color of meat may be breed-related, so it seems essential to conduct further studies; 4 . Duroc breed inclusion into Polish Landrace maternal line may be effective in crossbreeding, as it does not change the quality parameters.

\section{ACKNOWLEDGMENTS}

Research was realized with the project BIOFOOD - innovative, functional products of animal origin, 
no. POIG.01.01.02-014-090/09 co-financed by the European Union from the European Regional Development Fund within the Innovative Economy Operational Programme 2007-2013.

\section{RESUMO}

Cruzamentos com a raça Duroc permite a melhoria da qualidade da carne suína. No entanto, não há dados disponíveis na literatura sobre a influência específica da raça Duroc sobre características da carne após cruzamento com outras raças. O objetivo do trabalho foi avaliar o efeito do cruzamento de matrizes Polish Landrace com reprodutores Duroc sobre as características de carne de qualidade, em referência à própria raça Polish Landrace. O objeto do estudo foi o músculo dorsal lombar (Longissimus dorsi lumborum) obtidos de suínos das raça Polish Landrace breed e da raça mestiça entre Polish Landrace e Duroc. Medidas do comprimento do sarcômero foram realizadas por microscopia e a determinação da composição química básica foi analisada por espectrofotometria. A análise de textura de amostras de carne, realizada após tratamento térmico, foi expressa pela força de cisalhamento Warner-Bratzler enquanto a análise de cor foi realizada pelo sistema de cores CIE $L^{*} a * b *$. Não foram observadas diferenças no comprimento do sarcômero, força de cisalhamento e coloração entre as carnes provenientes das raças Polish Landrace e mestiça Polish Landrace x Duroc. A análise da composição química revelou maior teor de gordura e menor teor de cinzas na carne proveniente de animais da raça Polish Landrace. $\mathrm{O}$ trabalho permitiu concluir que o impacto da raça nas características da carne é possivelmente influenciado por outros fatores. No entanto, pode-se sugerir que a composição química básica no padrão de cor da carne está relacionada com a raça.

Palavras-chave: suínos, comprimento do sarcômero, conteúdo proteico e de gorduras, força de cisalhamento, cor.

\section{REFERENCES}

AMSA. 1995. Research Guidelines for Cookery, Sensory Evaluation, and Instrumental Tenderness Measurements of Fresh Meat. Amer Meat Sci Assoc, Chicago, IL, 105 p.

BLICHARSKI T AND HAMMERMEISTER A. 2013. Strategy for reconstruction and development of swine production in Poland until 2030 with the aim of improving the functioning of the pork production. Warszawa: Polski Związek Hodowców i Producentów Trzody Chlewnej "POLSUS" (in Polish), 260 p.

CRAWFORD SM, MOELLER SJ, ZERBY HN, IRVIN KM, Kuber PS, VELlEMAN SG AND LEedS TD. 2010. Effects of cooked temperature on pork tenderness and relationships among muscle physiology and pork quality traits in loins from Landrace and Berkshire swine. Meat Sci 84: 607-612.

CROsS HR, West RL AND DUTSON TR. 1981. Comparison of methods for measuring sarcomere length in beef semitendinosus muscle. Meat Sci 5: 261-266.

DILGER AC, RINCKER PJ, EGGERT JM, MCKEITH FK AND KILlefer J. 2010. Pork tenderness and postmortem tenderization: correlations with meat quality traits and the impact of sire line. J Muscle Foods 21: 529-544.

FAO. 1990. http://www.fao.org/docrep/003/x6932e/X6932E05. htm\#ch5. Accessed on October 28, 2014.

FLOROWSKI T, PISULA A, ADAMCZAK L, BUCZYŃSKI JT AND ORZECHOWSKA B. 2006a. Technological parametres of meat in pigs of two Polish local breeds - Zlotnicka Spotted and Pulawska. Anim Sci Pap Rep 24: 217-224.

FLOROWSKI T, PISULA A, SŁOWINSKI M AND ORZECHOWSKA B. 2006b. Processing suitability of pork from different breeds reared in Poland. Acta Sci Pol Technol Aliment 5: $55-64$.

GJERLAUG-ENGER E, AASS L, ØDEGÅRD J AND VANGEN O. 2010. Genetic parameters of meat quality traits in two pig breeds measured by rapid methods. Animal 4: 1832-1843.

GUZEK D, GŁĄBSKA D, GŁĄBSKI K, PLEWA P, PLEWA R AND WIERZBICKA A. 2012a. Comparison of sarcomere length for two types of meat from animal family Suidae - analysis of measurements carried out by microscopic technique. Adv Sci Tech Res J 6: 13-17.

GuzeK D, GŁĄBsKa D, GŁĄBski K, Pogorzelski G, BARSZCZEWSLI J AND WIERZBICKA A. 2015. Relationships between sarcomere length and basic composition of infraspinatus and longissimus dorsi muscle. Turk J Vet Anim Sci 39: 96-101

GUZEK D, GŁĄBSKA D, SAKOWSKA A AND WIERZBICKA A. 2012b. Colour of pork loin produced of meat of animals fed with bioactive compounds forage. Pesq Agropec Bras 47: 1504-1510.

Hunt MC, ACton JC, Benedict RC, CALKins CR, CORNFORTH DP, JEREMIAH LE, OLSON DG, SALM CP, SAVELL JW AND SHIVAS SD. 1991. AMSA guidelines for meat color evaluation. In: Proceedings of the $44^{\text {th }}$ Annual Reciprocal Meat Conference, 9-12 July 1991, Kansas State University, Manhattan.

ISMAIL HA, LEE EJ, Ko KY AND AHN DU. 2009. Fat Content Influences the Color, Lipid Oxidation, and Volatiles of Irradiated Ground Beef. J Food Sci 74: 432-440. 
JELENÍKOVÁ J, PIPEK P AND MIYAHARA M. 2008. The effects of breed, sex, intramuscular fat and ultimate $\mathrm{pH}$ on pork tenderness. Eur Food Res Technol 227: 989-994.

JIANG YZ ET AL. 2012. Carcass and meat quality traits of four commercial pig crossbreeds in China. Genet Mol Res 11: 4447-4455.

JOSELL A. 2002. Factors controlling meat quality of pork in relation to breed and RN genotype. PhD thesis. Lund University. Sweden.

KIM IS, JIN SK, KIM CW, SONG YM, CHO KK AND CHUNG KH. 2008. The Effects of Pig Breeds on Proximate, Physicochemical, Cholesterol, Amino Acid, Fatty Acid and Sensory Properties of Loins. J Anim Sci Technol 50: 121-132.

KING DA, SHACKELFORD SD AND WHEELER TL. 2011. Relative contributions of animal and muscle effects to variation in beef lean color stability. J Anim Sci 89: 1434-1451.

LEWIS JR PK, BROWN CJ AND HECK MC. 1977. Fiber diameter, sarcomere length and tenderness of certain muscles of crossbred beef steers. J Anim Sci 45: 254-260.

LINDAHL G, KARLSSON AH, LUNDSTRÖM K AND ANDERSEN HJ. 2006. Significance of storage time on degree of blooming and colour stability of pork loin from different crossbreeds. Meat Sci 72: 603-612.

LONERGAN SM, HuFF-LONERGRAN E, ROWE LJ, KUHLERS DL AND JUNGST SB. 2001. Selection for lean growth efficiency in Duroc pigs influences pork quality. J Anim Sci 79: 2075-2085.

Monin G, LARZul C, Le Roy P, Culioli J, Mourot J, Rousset-AKrim S, TAlmant A, TOURAIlle C AND SELLIER P. 1999. Effects of the halothane genotype and slaughter weight on texture of pork. J Anim Sci 77: 408415.

Muchenje V, DZAma K, Chimonyo M, Strydom PE, HUGO A AND RAATS JG. 2009. Some biochemical aspects pertaining to beef eating quality and consumer health: a review. Food Chem 112: 279-289.

PREVOLNIK M, ČANDEK-POTOKAR M AND ŠKORJANC D. 2004. Ability of NIR spectroscopy to predict meat chemi- cal composition and quality - a review. Czech J Anim Sci 49: 500-510.

RAMÍREZ R AND CAVA R. 2007. Carcass composition and meat quality of three different Iberian $\times$ Duroc genotype pigs. Meat Sci 75: 388-396.

ROWE LJ, MADDOCK KR, LONERGAN SM AND HUFFLONERGAN E. 2004. Influence of early postmortem protein oxidation on beef quality. J Anim Sci 82: 785-793.

SMULDERS FJ, MARSH BB, SWARTZ DR, RUSSELL RL AND HOENECKE ME. 1990. Beef tenderness and sarcomere length. Meat Sci 28: 349-363.

TEIXEIRA A AND RodrigueS S. 2013. Pork Meat Quality of Preto Alentejano and Commercial Largewhite Landrace Cross. J Integrative Agric 12: 1961-1971.

Thornton JW, Alsmeyer RH AND DAVEY RJ. 1968. Genetic, Diet and Pig Age Effects on Pork Tenderness and Palatability. J Anim Sci 27: 1229-1232.

TIKK K. 2007. The Influence of Feeding and Aging on Pork Quality. PhD thesis. University of Agricultural Sciences. Swedish.

TSUKADA T, PAPPAS CT, MOROZ N, ANTIN PB, KOSTYUKOVA AS AND GREGORIO CC. 2010. Leiomodin-2 is an antagonist of tropomodulin- 1 at the pointed end of the thin filaments in cardiac muscle. J Cell Sci 15: 3136-3145.

WHEELER TL, SHACKELFORD SD AND KOOHMARAIE M. 2000. Variation in proteolysis, sarcomere length, collagen content, and tenderness among major pork muscles. J Anim Sci 78: 958-965.

WoOd JD, BROWN SN, NuTE GR, WhitTington FM, PERRY AM, JOHNSON SP AND ENSER M. 1996. Effects of breed, feed level and conditioning time on the tenderness of pork. Meat Sci 44: 105-112.

WOOD JD, NUTE GR, RICHARDSON RI, WHITTINGTON FM, Southwood O, Plastow G, Mansbridge R, DA COSTA N AND CHANG KC. 2004. Effects of breed, diet and muscle on fat deposition and eating quality in pigs. Meat Sci 67: 651-667. 